\title{
Política, Planejamento e Gestão em
}

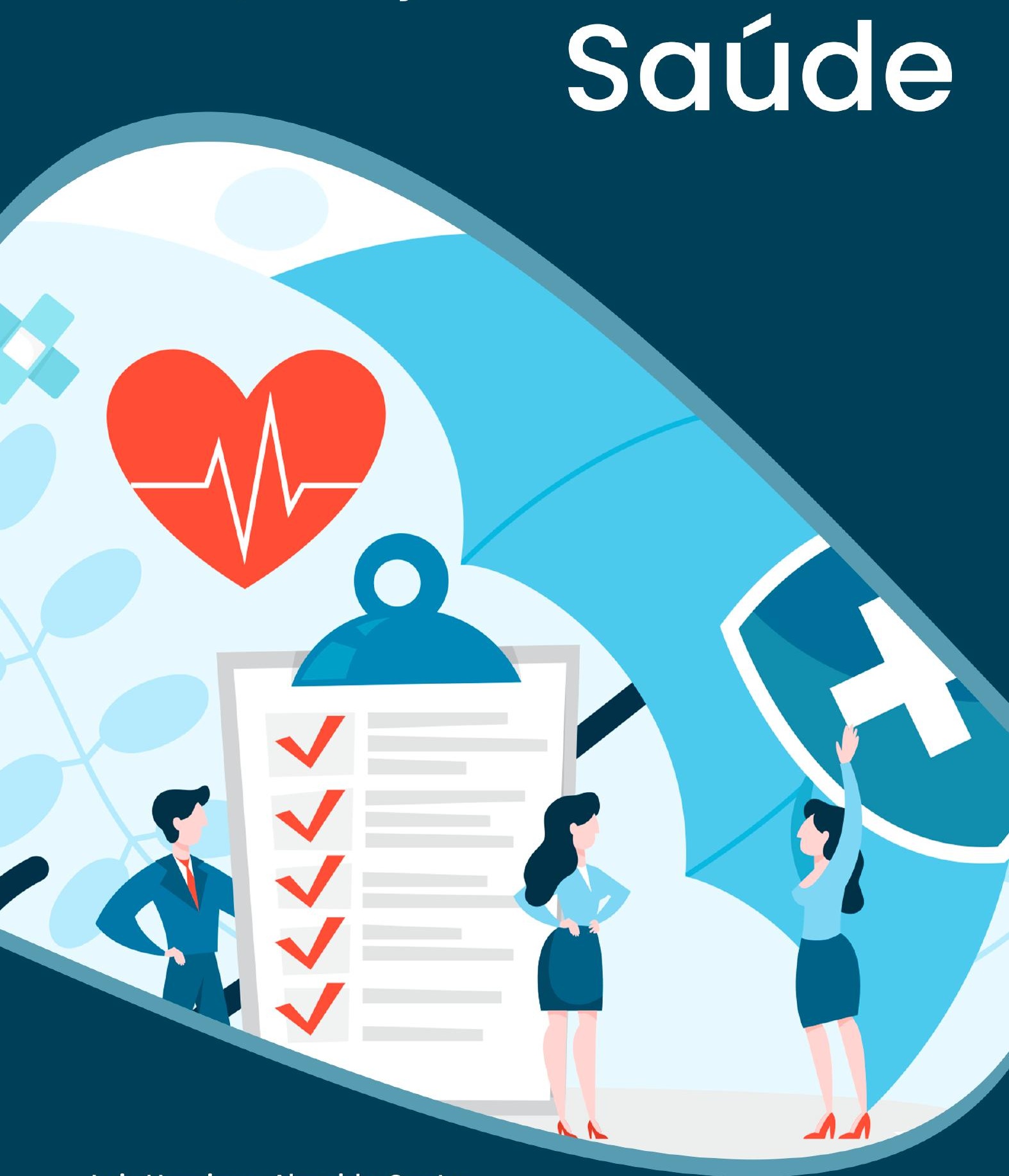

Luis Henrique Almeida Castro

Fernanda Viana de Carvalho Moreto

Thiago Teixeira Pereira

(Organizadores) 


\section{Política, Planejamento e Gestão em}

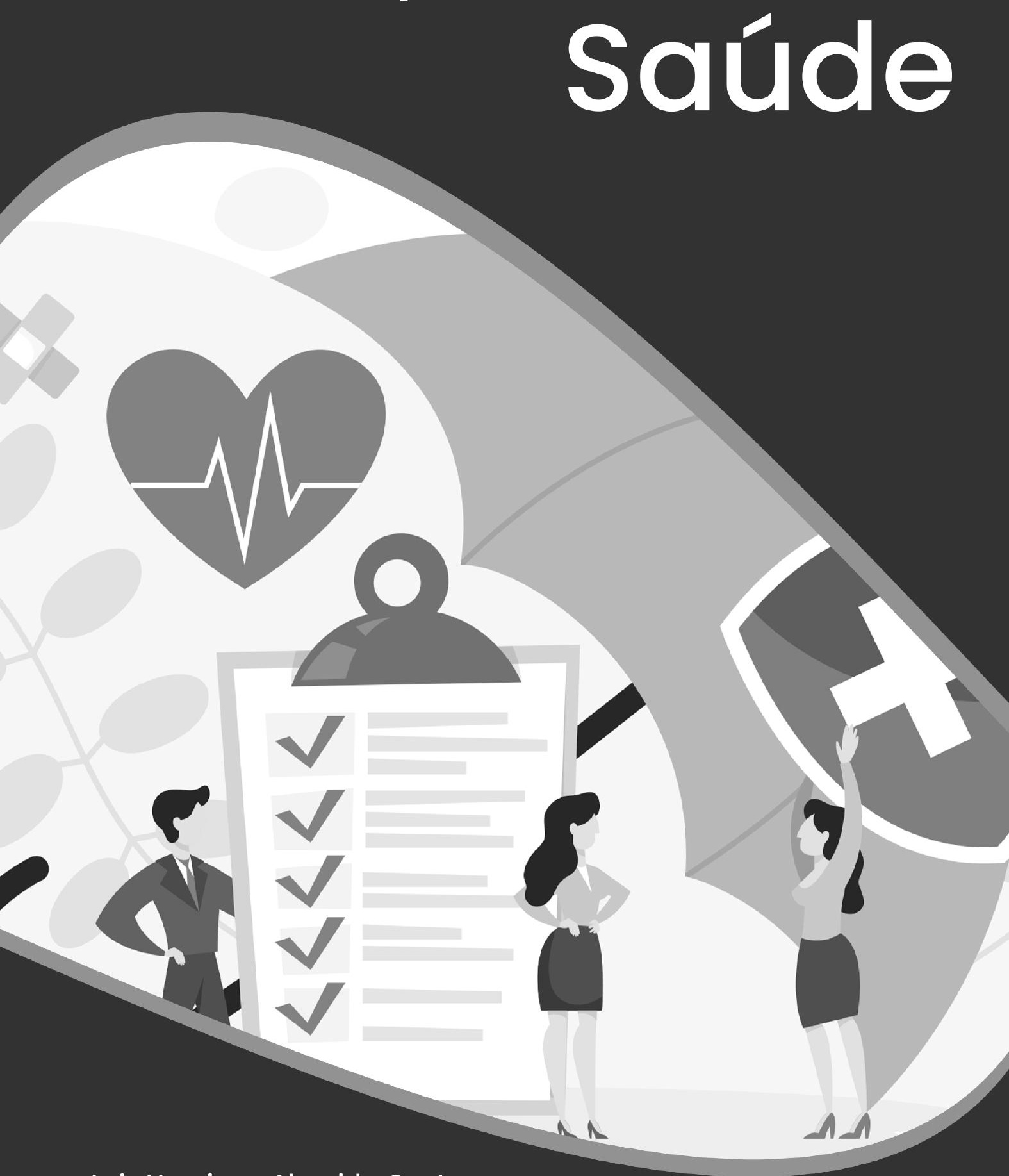

Luis Henrique Almeida Castro

Fernanda Viana de Carvalho Moreto

Thiago Teixeira Pereira

(Organizadores) 


\section{Editora Chefe}

Prof $^{\mathrm{a}} \mathrm{Dr}^{\mathrm{a}}$ Antonella Carvalho de Oliveira

Assistentes Editoriais

Natalia Oliveira

Bruno Oliveira

Flávia Roberta Barão

Bibliotecário

Maurício Amormino Júnior

Projeto Gráfico e Diagramação

Natália Sandrini de Azevedo

Camila Alves de Cremo

Karine de Lima Wisniewski

Luiza Alves Batista

Maria Alice Pinheiro

Imagens da Capa

Shutterstock

2020 by Atena Editora

Edição de Arte

Luiza Alves Batista

Copyright (C) Atena Editora

Copyright do Texto (C) 2020 Os autores

Copyright da Edição @ 2020 Atena Editora

Revisão Direitos para esta edição cedidos à Atena

Os Autores Editora pelos autores.

Todo o conteúdo deste livro está licenciado sob uma Licença de Atribuição Creative Commons. Atribuição 4.0 Internacional (CC BY 4.0).

O conteúdo dos artigos e seus dados em sua forma, correção e confiabilidade são de responsabilidade exclusiva dos autores, inclusive não representam necessariamente a posição oficial da Atena Editora. Permitido o download da obra e o compartilhamento desde que sejam atribuídos créditos aos autores, mas sem a possibilidade de alterá-la de nenhuma forma ou utilizá-la para fins comerciais.

A Atena Editora não se responsabiliza por eventuais mudanças ocorridas nos endereços convencionais ou eletrônicos citados nesta obra.

Todos os manuscritos foram previamente submetidos à avaliação cega pelos pares, membros do Conselho Editorial desta Editora, tendo sido aprovados para a publicação.

\section{Conselho Editorial}

\section{Ciências Humanas e Sociais Aplicadas}

Prof. Dr. Álvaro Augusto de Borba Barreto - Universidade Federal de Pelotas

Prof. Dr. Alexandre Jose Schumacher - Instituto Federal de Educação, Ciência e Tecnologia do Paraná

Prof. Dr. Américo Junior Nunes da Silva - Universidade do Estado da Bahia

Prof. Dr. Antonio Carlos Frasson - Universidade Tecnológica Federal do Paraná

Prof. Dr. Antonio Gasparetto Júnior - Instituto Federal do Sudeste de Minas Gerais

Prof. Dr. Antonio Isidro-Filho - Universidade de Brasília

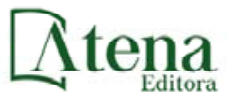


Prof. Dr. Carlos Antonio de Souza Moraes - Universidade Federal Fluminense

Prof $^{a}$ Dr $^{\text {a }}$ Cristina Gaio - Universidade de Lisboa

Prof. Dr. Daniel Richard Sant'Ana - Universidade de Brasília

Prof. Dr. Deyvison de Lima Oliveira - Universidade Federal de Rondônia

Prof $^{a}$ Dr $^{a}$ Dilma Antunes Silva - Universidade Federal de São Paulo

Prof. Dr. Edvaldo Antunes de Farias - Universidade Estácio de Sá

Prof. Dr. Elson Ferreira Costa - Universidade do Estado do Pará

Prof. Dr. Eloi Martins Senhora - Universidade Federal de Roraima

Prof. Dr. Gustavo Henrique Cepolini Ferreira - Universidade Estadual de Montes Claros

Prof $^{a} \mathrm{Dr}^{\mathrm{a}}$ Ivone Goulart Lopes - Istituto Internazionele delle Figlie de Maria Ausiliatrice

Prof. Dr. Jadson Correia de Oliveira - Universidade Católica do Salvador

Prof. Dr. Julio Candido de Meirelles Junior - Universidade Federal Fluminense

Prof $^{a} \mathrm{Dr}^{\mathrm{a}}$ Lina Maria Gonçalves - Universidade Federal do Tocantins

Prof. Dr. Luis Ricardo Fernandes da Costa - Universidade Estadual de Montes Claros

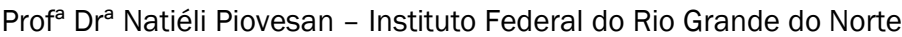

Prof. Dr. Marcelo Pereira da Silva - Pontifícia Universidade Católica de Campinas

Prof $^{a}$ Dr $^{a}$ Maria Luzia da Silva Santana - Universidade Federal de Mato Grosso do Sul

Prof $^{a}$ Dr $^{\text {a }}$ Paola Andressa Scortegagna - Universidade Estadual de Ponta Grossa

Prof $^{a}$ Dr $^{a}$ Rita de Cássia da Silva Oliveira - Universidade Estadual de Ponta Grossa

Prof. Dr. Rui Maia Diamantino - Universidade Salvador

Prof. Dr. Urandi João Rodrigues Junior - Universidade Federal do Oeste do Pará

Prof $^{a}$ Dr $^{a}$ Vanessa Bordin Viera - Universidade Federal de Campina Grande

Prof. Dr. William Cleber Domingues Silva - Universidade Federal Rural do Rio de Janeiro

Prof. Dr. Willian Douglas Guilherme - Universidade Federal do Tocantins

\section{Ciências Agrárias e Multidisciplinar}

Prof. Dr. Alexandre Igor Azevedo Pereira - Instituto Federal Goiano

Prof $^{\mathrm{a}} \mathrm{Dr}^{\mathrm{a}}$ Carla Cristina Bauermann Brasil - Universidade Federal de Santa Maria

Prof. Dr. Antonio Pasqualetto - Pontifícia Universidade Católica de Goiás

Prof. Dr. Cleberton Correia Santos - Universidade Federal da Grande Dourados

Prof $^{a}$ Dr $^{a}$ Daiane Garabeli Trojan - Universidade Norte do Paraná

Prof $^{a}$ Dr $^{a}$ Diocléa Almeida Seabra Silva - Universidade Federal Rural da Amazônia

Prof. Dr. Écio Souza Diniz - Universidade Federal de Viçosa

Prof. Dr. Fábio Steiner - Universidade Estadual de Mato Grosso do Sul

Prof. Dr. Fágner Cavalcante Patrocínio dos Santos - Universidade Federal do Ceará

Prof $^{a}$ Dr $^{a}$ Girlene Santos de Souza - Universidade Federal do Recôncavo da Bahia

Prof. Dr. Jael Soares Batista - Universidade Federal Rural do Semi-Árido

Prof. Dr. Júlio César Ribeiro - Universidade Federal Rural do Rio de Janeiro

Prof $^{a}$ Dr $^{a}$ Lina Raquel Santos Araújo - Universidade Estadual do Ceará

Prof. Dr. Pedro Manuel Villa - Universidade Federal de Viçosa

Prof $^{a}$ Dr $^{a}$ Raissa Rachel Salustriano da Silva Matos - Universidade Federal do Maranhão

Prof. Dr. Ronilson Freitas de Souza - Universidade do Estado do Pará

Prof $^{\mathrm{a}} \mathrm{Dr}^{\mathrm{a}}$ Talita de Santos Matos - Universidade Federal Rural do Rio de Janeiro

Prof. Dr. Tiago da Silva Teófilo - Universidade Federal Rural do Semi-Árido

Prof. Dr. Valdemar Antonio Paffaro Junior - Universidade Federal de Alfenas

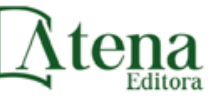

Ano 2020 


\section{Ciências Biológicas e da Saúde}

Prof. Dr. André Ribeiro da Silva - Universidade de Brasília

Prof $^{a}$ Dr $^{a}$ Anelise Levay Murari - Universidade Federal de Pelotas

Prof. Dr. Benedito Rodrigues da Silva Neto - Universidade Federal de Goiás

Prof $^{a}$ Dr $^{a}$ Débora Luana Ribeiro Pessoa - Universidade Federal do Maranhão

Prof. Dr. Douglas Siqueira de Almeida Chaves -Universidade Federal Rural do Rio de Janeiro

Prof. Dr. Edson da Silva - Universidade Federal dos Vales do Jequitinhonha e Mucuri

Prof $^{a}$ Dr $^{a}$ Eleuza Rodrigues Machado - Faculdade Anhanguera de Brasília

Prof $^{a}$ Dr $^{a}$ Elane Schwinden Prudêncio - Universidade Federal de Santa Catarina

Prof ${ }^{a}$ Dr $^{a}$ Eysler Gonçalves Maia Brasil - Universidade da Integração Internacional da Lusofonia Afro-Brasileira

Prof. Dr. Ferlando Lima Santos - Universidade Federal do Recôncavo da Bahia

Prof $^{\mathrm{a}}$ Dr $^{\mathrm{a}}$ Gabriela Vieira do Amaral - Universidade de Vassouras

Prof. Dr. Gianfábio Pimentel Franco - Universidade Federal de Santa Maria

Prof. Dr. Helio Franklin Rodrigues de Almeida - Universidade Federal de Rondônia

Prof $^{a}$ Dr $^{\mathrm{a}}$ Iara Lúcia Tescarollo - Universidade São Francisco

Prof. Dr. Igor Luiz Vieira de Lima Santos - Universidade Federal de Campina Grande

Prof. Dr. Jefferson Thiago Souza - Universidade Estadual do Ceará

Prof. Dr. Jesus Rodrigues Lemos - Universidade Federal do Piauí

Prof. Dr. Jônatas de França Barros - Universidade Federal do Rio Grande do Norte

Prof. Dr. José Max Barbosa de Oliveira Junior - Universidade Federal do Oeste do Pará

Prof. Dr. Luís Paulo Souza e Souza - Universidade Federal do Amazonas

Prof $^{\mathrm{a}} \mathrm{Dr}^{\mathrm{a}}$ Magnólia de Araújo Campos - Universidade Federal de Campina Grande

Prof. Dr. Marcus Fernando da Silva Praxedes - Universidade Federal do Recôncavo da Bahia

Prof $^{\mathrm{a}} \mathrm{Dr}^{\mathrm{a}}$ Mylena Andréa Oliveira Torres - Universidade Ceuma

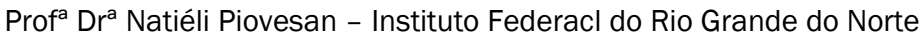

Prof. Dr. Paulo Inada - Universidade Estadual de Maringá

Prof. Dr. Rafael Henrique Silva - Hospital Universitário da Universidade Federal da Grande Dourados

Prof $^{a}$ Dr $^{a}$ Regiane Luz Carvalho - Centro Universitário das Faculdades Associadas de Ensino

Prof $^{a}$ Dr $^{a}$ Renata Mendes de Freitas - Universidade Federal de Juiz de Fora

Prof $^{a}$ Dr $^{\text {a }}$ Vanessa Lima Gonçalves - Universidade Estadual de Ponta Grossa

Prof $^{a}$ Dr $^{a}$ Vanessa Bordin Viera - Universidade Federal de Campina Grande

\section{Ciências Exatas e da Terra e Engenharias}

Prof. Dr. Adélio Alcino Sampaio Castro Machado - Universidade do Porto

Prof. Dr. Alexandre Leite dos Santos Silva - Universidade Federal do Piauí

Prof. Dr. Carlos Eduardo Sanches de Andrade - Universidade Federal de Goiás

Prof $^{a}$ Dr $^{\mathrm{a}}$ Carmen Lúcia Voigt - Universidade Norte do Paraná

Prof. Dr. Douglas Gonçalves da Silva - Universidade Estadual do Sudoeste da Bahia

Prof. Dr. Eloi Rufato Junior - Universidade Tecnológica Federal do Paraná

Prof. Dr. Fabrício Menezes Ramos - Instituto Federal do Pará

Prof $^{a}$ Dra. Jéssica Verger Nardeli - Universidade Estadual Paulista Júlio de Mesquita Filho

Prof. Dr. Juliano Carlo Rufino de Freitas - Universidade Federal de Campina Grande

Prof ${ }^{a}$ Dr $^{a}$ Luciana do Nascimento Mendes - Instituto Federal de Educação, Ciência e Tecnologia do Rio Grande do Norte

Prof. Dr. Marcelo Marques - Universidade Estadual de Maringá

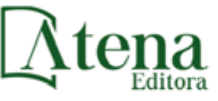

Ano 2020 


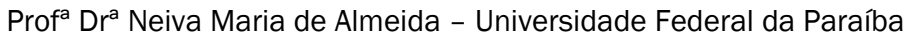

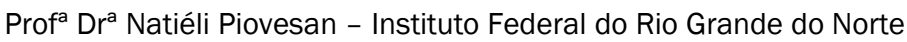

Prof. Dr. Takeshy Tachizawa - Faculdade de Campo Limpo Paulista

\section{Linguística, Letras e Artes}

Prof $^{a}$ Dr $^{a}$ Adriana Demite Stephani - Universidade Federal do Tocantins

Prof $^{a}$ Dr $^{a}$ Angeli Rose do Nascimento - Universidade Federal do Estado do Rio de Janeiro

Prof $^{a}$ Dr $^{a}$ Carolina Fernandes da Silva Mandaji - Universidade Tecnológica Federal do Paraná

Prof $^{a}$ Dr $^{\text {a }}$ Denise Rocha - Universidade Federal do Ceará

Prof. Dr. Fabiano Tadeu Grazioli - Universidade Regional Integrada do Alto Uruguai e das Missões

Prof. Dr. Gilmei Fleck - Universidade Estadual do Oeste do Paraná

Prof $^{a}$ Dr $^{a}$ Keyla Christina Almeida Portela - Instituto Federal de Educação, Ciência e Tecnologia do Paraná



Prof $^{a}$ Dr $^{a}$ Sandra Regina Gardacho Pietrobon - Universidade Estadual do Centro-Oeste

Prof $^{a}$ Dr $^{\text {a }}$ Sheila Marta Carregosa Rocha - Universidade do Estado da Bahia

\section{Conselho Técnico Científico}

Prof. Me. Abrãao Carvalho Nogueira - Universidade Federal do Espírito Santo

Prof. Me. Adalberto Zorzo - Centro Estadual de Educação Tecnológica Paula Souza

Prof. Me. Adalto Moreira Braz - Universidade Federal de Goiás

Prof. Dr. Adaylson Wagner Sousa de Vasconcelos - Ordem dos Advogados do Brasil/Seccional Paraíba

Prof. Dr. Adilson Tadeu Basquerote Silva - Universidade para o Desenvolvimento do Alto Vale do Itajaí

Prof. Me. Alexsandro Teixeira Ribeiro - Centro Universitário Internacional

Prof. Me. André Flávio Gonçalves Silva - Universidade Federal do Maranhão

Prof ${ }^{a}$ Ma. Anne Karynne da Silva Barbosa - Universidade Federal do Maranhão

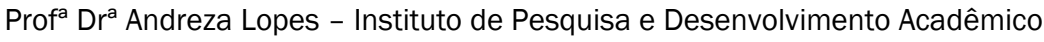

Prof $^{a}$ Dr $^{a}$ Andrezza Miguel da Silva - Faculdade da Amazônia

Prof. Dr. Antonio Hot Pereira de Faria - Polícia Militar de Minas Gerais

Prof. Me. Armando Dias Duarte - Universidade Federal de Pernambuco

Prof $^{a}$ Ma. Bianca Camargo Martins - UniCesumar

Prof $^{a}$ Ma. Carolina Shimomura Nanya - Universidade Federal de São Carlos

Prof. Me. Carlos Antônio dos Santos - Universidade Federal Rural do Rio de Janeiro

Prof. Ma. Cláudia de Araújo Marques - Faculdade de Música do Espírito Santo

Prof $^{a}$ Dr $^{a}$ Cláudia Taís Siqueira Cagliari - Centro Universitário Dinâmica das Cataratas

Prof. Me. Clécio Danilo Dias da Silva - Universidade Federal do Rio Grande do Norte

Prof. Me. Daniel da Silva Miranda - Universidade Federal do Pará

Prof $^{\mathrm{a}}$ Ma. Daniela da Silva Rodrigues - Universidade de Brasília

Prof $^{a}$ Ma. Daniela Remião de Macedo - Universidade de Lisboa

Prof ${ }^{a}$ Ma. Dayane de Melo Barros - Universidade Federal de Pernambuco

Prof. Me. Douglas Santos Mezacas - Universidade Estadual de Goiás

Prof. Me. Edevaldo de Castro Monteiro - Embrapa Agrobiologia

Prof. Me. Eduardo Gomes de Oliveira - Faculdades Unificadas Doctum de Cataguases

Prof. Me. Eduardo Henrique Ferreira - Faculdade Pitágoras de Londrina

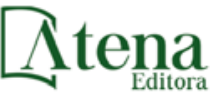

Ano 2020 
Prof. Dr. Edwaldo Costa - Marinha do Brasil

Prof. Me. Eliel Constantino da Silva - Universidade Estadual Paulista Júlio de Mesquita

Prof. Me. Ernane Rosa Martins - Instituto Federal de Educação, Ciência e Tecnologia de Goiás

Prof. Me. Euvaldo de Sousa Costa Junior - Prefeitura Municipal de São João do Piauí

Prof $^{a}$ Ma. Fabiana Coelho Couto Rocha Corrêa - Centro Universitário Estácio Juiz de Fora

Prof. Dr. Fabiano Lemos Pereira - Prefeitura Municipal de Macaé

Prof. Me. Felipe da Costa Negrão - Universidade Federal do Amazonas

Prof $^{a}$ Dr $^{a}$ Germana Ponce de Leon Ramírez - Centro Universitário Adventista de São Paulo

Prof. Me. Gevair Campos - Instituto Mineiro de Agropecuária

Prof. Dr. Guilherme Renato Gomes - Universidade Norte do Paraná

Prof. Me. Gustavo Krahl - Universidade do Oeste de Santa Catarina

Prof. Me. Helton Rangel Coutinho Junior - Tribunal de Justiça do Estado do Rio de Janeiro

Prof $^{\mathrm{a}} \mathrm{Ma}$. Isabelle Cerqueira Sousa - Universidade de Fortaleza

Prof $^{a}$ Ma. Jaqueline Oliveira Rezende - Universidade Federal de Uberlândia

Prof. Me. Javier Antonio Albornoz - University of Miami and Miami Dade College

Prof. Me. Jhonatan da Silva Lima - Universidade Federal do Pará

Prof. Dr. José Carlos da Silva Mendes - Instituto de Psicologia Cognitiva, Desenvolvimento Humano e Social

Prof. Me. Jose Elyton Batista dos Santos - Universidade Federal de Sergipe

Prof. Me. José Luiz Leonardo de Araujo Pimenta - Instituto Nacional de Investigación Agropecuaria Uruguay

Prof. Me. José Messias Ribeiro Júnior - Instituto Federal de Educação Tecnológica de Pernambuco

Prof $^{a}$ Dr $^{\mathrm{a}}$ Juliana Santana de Curcio - Universidade Federal de Goiás

Prof ${ }^{a}$ Ma. Juliana Thaisa Rodrigues Pacheco - Universidade Estadual de Ponta Grossa

Prof $^{a}$ Dr $^{a}$ Kamilly Souza do Vale - Núcleo de Pesquisas Fenomenológicas/UFPA

Prof. Dr. Kárpio Márcio de Siqueira - Universidade do Estado da Bahia

Prof $^{a}$ Dr $^{a}$ Karina de Araújo Dias - Prefeitura Municipal de Florianópolis

Prof. Dr. Lázaro Castro Silva Nascimento - Laboratório de Fenomenologia \& Subjetividade/UFPR

Prof. Me. Leonardo Tullio - Universidade Estadual de Ponta Grossa

Prof ${ }^{a}$ Ma. Lilian Coelho de Freitas - Instituto Federal do Pará

Prof $^{a}$ Ma. Liliani Aparecida Sereno Fontes de Medeiros - Consórcio CEDERJ

Prof $^{a}$ Dr $^{a}$ Lívia do Carmo Silva - Universidade Federal de Goiás

Prof. Dr. Lucio Marques Vieira Souza - Secretaria de Estado da Educação, do Esporte e da Cultura de Sergipe

Prof. Me. Luis Henrique Almeida Castro - Universidade Federal da Grande Dourados

Prof. Dr. Luan Vinicius Bernardelli - Universidade Estadual do Paraná

Prof. Dr. Michel da Costa - Universidade Metropolitana de Santos

Prof. Dr. Marcelo Máximo Purificação - Fundação Integrada Municipal de Ensino Superior

Prof. Me. Marcos Aurelio Alves e Silva - Instituto Federal de Educação, Ciência e Tecnologia de São Paulo

Prof ${ }^{a}$ Ma. Maria Elanny Damasceno Silva - Universidade Federal do Ceará

Prof ${ }^{a}$ Ma. Marileila Marques Toledo - Universidade Federal dos Vales do Jequitinhonha e Mucuri

Prof. Me. Ricardo Sérgio da Silva - Universidade Federal de Pernambuco

Prof ${ }^{a}$ Ma. Renata Luciane Polsaque Young Blood - UniSecal

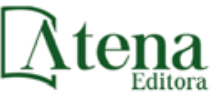

Ano 2020 
Prof. Me. Robson Lucas Soares da Silva - Universidade Federal da Paraíba

Prof. Me. Sebastião André Barbosa Junior - Universidade Federal Rural de Pernambuco

Prof $^{a}$ Ma. Silene Ribeiro Miranda Barbosa - Consultoria Brasileira de Ensino, Pesquisa e Extensão

Prof $^{a}$ Ma. Solange Aparecida de Souza Monteiro - Instituto Federal de São Paulo

Prof. Me. Tallys Newton Fernandes de Matos - Faculdade Regional Jaguaribana

Prof $^{a}$ Ma. Thatianny Jasmine Castro Martins de Carvalho - Universidade Federal do Piauí

Prof. Me. Tiago Silvio Dedoné - Colégio ECEL Positivo

Prof. Dr. Welleson Feitosa Gazel - Universidade Paulista 


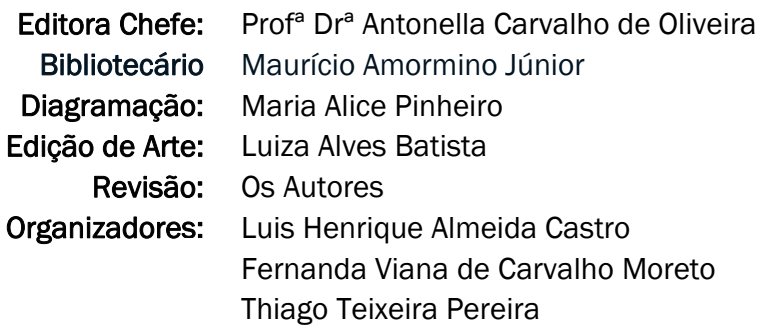

Dados Internacionais de Catalogação na Publicação (CIP) (eDOC BRASIL, Belo Horizonte/MG)

P766 Política, planejamento e gestão em saúde 1 / Organizadores Luis Henrique Almeida Castro, Fernanda Viana de Carvalho Moreto, Thiago Teixeira Pereira. - Ponta Grossa, PR: Atena, 2020.

Formato: PDF

Requisitos de sistema: Adobe Acrobat Reader Modo de acesso: World Wide Web

Inclui bibliografia

ISBN 978-65-5706-300-2

DOI 10.22533/at.ed.002202808

1. Política de saúde. 2. Saúde coletiva. 3. Saúde pública. I.Castro, Luis Henrique Almeida. II. Moreto, Fernanda Viana de Carvalho. III. Pereira, Thiago Teixeira.

Elaborado por Maurício Amormino Júnior - CRB6/2422

Atena Editora

Ponta Grossa - Paraná - Brasil Telefone: +55 (42) 3323-5493 www.atenaeditora.com.br contato@atenaeditora.com.br

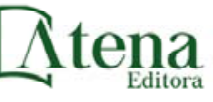

Ano 2020 


\section{APRESENTAÇÃO}

A obra "Política, Planejamento e Gestão em Saúde" emerge como uma fonte de pesquisa robusta, que explora o conhecimento em suas diferentes faces, abrangendo diversos estudos.

Por ser uma área que investiga processos de formulação, implementação, planejamento, execução e avaliação de políticas, sistemas, serviços e práticas de saúde, a sua relevância no campo das ciências da saúde é indiscutível, revelando a multiplicidade de aportes teóricos e metodológicos, de caráter interdisciplinar, transdisciplinar e multiprofissional, influenciados por diferentes campos de conhecimento.

No intuito de promover e estimular o aprendizado dos leitores sobre esta temática, os estudos selecionados fornecem concepções fundamentadas em diferentes métodos de pesquisa.

Constituído por dez volumes, este e-Book é composto por 212 textos científicos que refletem sobre as ciências da saúde, seus avanços recentes e as necessidades sociais da população, dos profissionais de saúde e do relacionamento entre ambos.

Visando uma organização didática, a obra está dividida de acordo com seis temáticas abordadas em cada pesquisa, sendo elas: "Análises e Avaliações Comparativas" que traz como foco estudos que identificam não apenas diferentes características entre os sistemas, mas também de investigação onde mais de um nível de análise é possível; "Levantamento de Dados e Estudos Retrospectivos" correspondente aos estudos procedentes do conjunto de informações que já foram coletadas durante um processo de investigação distinta; "Entrevistas e Questionários" através da coleta de dados relativos ao processo de pesquisa; "Estudos Interdisciplinares" que oferecem possibilidades do diálogo entre as diferentes áreas e conceitos; "Estudos de Revisão da Literatura" que discutem o estado da arte da ciência baseada em evidência sugerindo possibilidades, hipóteses e problemáticas técnicas para a prática clínica; e, por fim, tem-se a última temática "Relatos de Experiências e Estudos de Caso" através da comunicação de experiência e de vivência em saúde apresentando aspectos da realidade clínica, cultural e social que permeiam a ciência no Brasil.

Enquanto organizadores, através deste e-Book publicado pela Atena Editora, convidamos o leitor a gerar, resgatar ou ainda aprimorar seu senso investigativo no intuito de estimular ainda mais sua busca pelo conhecimento na área científica. Por fim, agradecemos aos autores pelo empenho e dedicação, que possibilitaram a construção dessa obra de excelência, e o trabalho aqui presente pode ser um agente transformador por gerar conhecimento em uma área fundamental do desenvolvimento como a saúde.

Boa leitura!

Luis Henrique Almeida Castro Fernanda Viana de Carvalho Moreto Thiago Teixeira Pereira 


\section{SUMÁRIO}

CAPÍTULO 1

ANÁLISE MICROBIOLÓGICA DE COLIFORMES TERMOTOLERANTES EM GOMAS DE MANDIOCA ADQUIRIDAS EM FEIRAS DO MUNICÍPIO DE BELÉM

Camélia Santos de Viveiros

Suely Maria Ribeiro da Silva

Jordana Caroline Sousa Mourão

Bianca Alejandra Valdivia Frazão Alves

Dryele Kristine Oliveira Melo

Lorena Barroso de Araújo

Gabriela Melo de Oliveira

DOI 10.22533/at.ed.0022028081

CAPÍTULO 2

ANÁLISE POSTURAL: UM ESTUDO SOBRE PRÁTICA DE ATIVIDADE FÍSICA, POSTURA AO SENTAR E ESTADO NUTRICIONAL DE ESCOLARES

Regina Célia Vilanova-Campelo

Erica Ravena Alves Campelo

Raquel Vilanova Araújo

DOI 10.22533/at.ed.0022028082

CAPÍTULO 3 17

AVALIAÇÃO DA QUALIDADE MICROBIOLÓGICA DE FARINHAS DE MANDIOCA E TAPIOCA PRODUZIDAS NO MUNICÍPIO DE CASTANHAL-PA

Marcos Daniel das Neves Sousa

Francisca Mariane Martins Araújo

Ana Jessica Mendes Honorato

Elane Giselle Silva dos Santos

Giovanna Gabriela Silva Medeiros

Dailene Tanyele Cordeiro Ares

Kássia Rodrigues da Costa Sena

Khettely Samily Freire Correa

Victor Cesar da Silva Oliveira

Adrianne Maria Brito Pinheiro da Rosa

Ingryd Rodrigues Martins

Anna Paula Pereira Barbosa

DOI 10.22533/at.ed.0022028083

CAPÍTULO 4 .26

AVALIAÇÃO DO EQUILIBRIO POSTURAL E DO RISCO DE QUEDAS EM IDOSOS ATIVOS

Fasíla de Nazaré Lobato Pinheiro

Milciana Urbiêta Barboza

Patrícia Lira Bizerra

Lizandra Alvares Félix Barros

DOI 10.22533/at.ed.0022028084 
AVALIAÇÃO DO NÍVEL DE CONTAMINAÇÃO FÍSICA EM FARINHAS DE MANDIOCA E TAPIOCA PRODUZIDAS NA CIDADE DE CASTANHAL - PA

Marcos Daniel das Neves Sousa

Francisca Mariane Martins Araújo

Ana Jessica Mendes Honorato

Elane Giselle Silva dos Santos

Giovanna Gabriela Silva Medeiros

Dailene Tanyele Cordeiro Ares

Kássia Rodrigues da Costa Sena

Khettely Samily Freire Correa

Victor Cesar da Silva Oliveira

Adrianne Maria Brito Pinheiro da Rosa

Ingryd Rodrigues Martins

Anna Paula Pereira Barbosa

DOI 10.22533/at.ed.0022028085

CAPÍTULO 6

AVALIAÇÃO HIGIÊNICO-SANITÁRIA DO PESCADO COMERCIALIZADO NO MERCADO MUNICIPAL DE ABAETETUBA-PA

Eleda Maria Paixão Xavier Neves

Elizayne Yza Xavier Farias

Aline Maciel Araújo

Gleice Vasconcelos da Silva Pereira

Glauce Vasconcelos da Silva Pereira.

Natácia Silva e Silva

DOI 10.22533/at.ed.0022028086

CAPÍTULO 7

AVALIAÇÃO HISTOPATOLÓGICA DA HEPATITE AUTOIMUNE EM BIÓPSIAS DE PACIENTES DO INSTITUTO DO FÍGADO DE PERNAMBUCO (IFP)

Isabela Cristina de Farias Andrade

Ana Clara Santos Costa

Brayan Marques da Costa

Débora Dantas Nucci Cerqueira

Gabrielle Rodrigues Rangel

Sura Wanessa Santos Rocha

DOI 10.22533/at.ed.0022028087

CAPÍTULO 8

AVALIAÇÃO MICROBIOLÓGICA E ACEITABILIDADE DE BOLO DE LARANJA ADICIONADO DE FARINHA DE CARCAÇA DE TILÁPIA DO NILO

Adriana Maria Centenaro

Andressa Inez Centenaro

Denise Pastore de Lima

Saraspathy Naidoo Terroso Gama de Mendonça

DOI 10.22533/at.ed.0022028088 
BIOCOMPATIBILIDADE DAS CÉLULAS-TRONCO MESENQUIMAIS DE GELÉIA DE WHARTON DE CAPRINOS EM MATRIZ POROSA DE ÓLEO DE BURITI (MAURITIA FLEXUOSA)
Maria Acelina Martins de Carvalho
Napoleão Martins Argôlo Neto
Huanna Waleska Soares Rodrigues
Fernando da Silva Reis
Camila Ernanda Sousa de Carvalho
Elis Rosélia Dutra de Freitas Siqueira Silva
Isnayra Kerolaynne Carneiro Pacheco
Ana Cristina Vasconcelos Fialho
José Milton Elias de Matos

DOI 10.22533/at.ed.0022028089

CAPÍTULO 10

COMPARAÇÃO DA TÉCNICA DE MICRONÚCLEO (MN) PARA AVALIAÇÃO DA MUTAGENICIDADE DAS CÉLULAS DA MUCOSA ORAL

Douglas Fernandes da Silva

Vagner Pires de Campos Junior

Lucimara Pereira Lorente

Milena Ferreira Machado

Isabela de Carvalho Vazquez

DOI 10.22533/at.ed.00220280810

CAPÍTULO 11

DOMÍNIO DA IMPLEMENTAÇÃO DA FERRAMENTA DE QUALIDADE DE BOAS PRÁTICAS DE FABRICAÇÃO EM MATADOUROS FRIGORÍFICOS NO MUNICÍPIO DE CASTANHAL, PARÁ

Isabelly Silva Amorim

Danyelly Silva Amorim

Andreza de Brito Leal

Ana Beatriz Rocha Lopes

Jamille de Sousa Monteiro

Marcos Daniel das Neves Sousa

Kássia Rodrigues da Costa Sena

Adriano Cesar Calandrini Braga

Ana Carla Alves Pelais

DOI 10.22533/at.ed.00220280811

CAPÍTULO 12.

ESPIRITUALIDADE, COPING RELIGIOSO ESPIRITUAL E QUALIDADE DE VIDA EM PACIENTES ONCOLÓGICOS EM UM HOSPITAL PÚBLICO NO NORDESTE DO BRASIL

Eloysa Almeida de Souza

Bianca Dantas dos Santos Ramos

Lucivana Quézia Mergulhão da Silva

Arturo de Pádua Walfrido Jordán

Leopoldo Nelson Fernandes Barbosa

DOI 10.22533/at.ed.00220280812 
CAPÍTULO 13

MICROBIOLOGICAL POLLUTION OF INTRAMURAL AIR IN A SCHOOL IN THE CITY OF LA PLATA AND ITS IMPACT ON RESPIRATORY CONDITIONS

Myrian Elizabeth Aguilar

Pedro Brignoles

José Viegas Caetano

Marina Acosta

Andrés Porta

Andrea Astoreca

DOI 10.22533/at.ed.00220280813

SOBRE OS ORGANIZADORES.

ÍNDICE REMISSIVO 
Myrian Elizabeth Aguilar

Environmental Research Center (CIM), Faculty of Exacts Science, National University of La Plata, 47th and 115th Street (B1900ASH) La

Plata, Argentina.

\section{Pedro Brignoles}

Teaching staff of Hygiene and Public Health, Faculty of Exacts Science, National University of La Plata.47th and 115th Street (B1900ASH)

La Plata, Argentina.

\section{José Viegas Caetano}

Teaching staff of Clinical Microbiology, Faculty of Exacts Science, National University of La Plata.47th and 115th Street (B1900ASH) La

Plata, Argentina.

\section{Marina Acosta}

Center for Research and Development in Industrial Fermentations (CINDEFI), Technical staff of the National Council of Scientific and Technical Research (CONICET), Faculty of

Exacts Science, National University of La Plata.47th and 115th Street (B1900ASH) La Plata, Argentina.

\section{Andrés Porta}

Environmental Research Center (CIM). Researcher of the National Council of Scientific and Technical Research (CONICET), Faculty of Exacts Science, National University of La Plata, 47th and 115th Street (B1900ASH) La Plata, Argentina.
Center for Research and Development

in Industrial Fermentations (CINDEFI). Researcher of the National Council of Scientific and Technical Research (CONICET), Faculty of Exacts Science, National University of La Plata.47th and 115th Street (B1900ASH) La Plata, Argentina. https://orcid.org/0000-00033518-6012

ABSTRACT: The effects of indoor air pollution have received increased attention worldwide. Schools are places with a high level of activity and population density of children, where different pollutants from both indoor and outdoor sources may be introduced and persist for a long time. Indoor air quality in school buildings is characterized by various pollutants, such as volatile organic compounds (VOCs), particulate matter (PM2.5 and PM10), fungi and bacteria. In this context, the objective of this study was to describe and characterize the microbial contamination present in the indoor atmosphere of a public school in our city in relation to its impact with the respiratory disorders of those who come to that establishment. The predominant genera of airborne fungi isolated in indoor air of the college were Cladosporium, Epicoccum, Ulocladium, Aspergillus, Fusarium and Penicillium. The predominant bacteria in this work were some species belonging to the genus Pseudomonas and Bacillus, added to Micrococcus luteus, which persisted in the different sampled seasons. Mold and bacteria monitoring shows differences in the found genera/species in the assayed seasons of 
the year, which is correlated with the variation in environmental conditions. This fact does not seem to be affecting the respiratory physiological parameters of the evaluated children since they are within normal values, according to the international literature. When compared with the international bibliography, they show to be slightly smaller, highlighting the importance of having specific equations to the region under study. In future studies, an attempt will be made to correlate the found microorganisms with the profiles of volatile metabolites organic compounds (MVOC's) and their effects on the respiratory health of a group of adolescents from La Plata city.

KEYWORDS: biological pollution, air quality, health, School environments.

\section{I INTRODUCTION}

The effects of indoor air pollution have received increased attention worldwide. Various studies have indicated that exposure to some pollutants can be two to five times higher in intramural environments than outside. In recent years, it has become especially relevant the term "sick building syndrome" associated to a wide range of symptoms or diseases that people who inhabit these spaces attribute to the building itself (BALOCH et al., 2020).

Schools are places with a high level of activity and population density of children, where different pollutants from both indoor and outdoor sources may be introduced and persist for a long time (CHITHRA and NAGENDRA 2018). Indoor air quality (IAQ) has a significant impact on health, wellbeing and human performance (GUAIS et al., 2011), particularly in children, who are more vulnerable and sensitive to the presence of air pollutants (LAZOVIC et al., 2015).

Indoor air quality in school buildings is characterized by various pollutants, such as volatile organic compounds (VOCs), particulate matter (PM2.5 and PM10), fungi and bacteria (MADUREIRA et al. 2009, 2012, 2015; SALONEN et al. 2015). Changes in the health status of students exposed to poor indoor air quality may manifest in various acute and chronic symptoms as well as in the form of various specific diseases, student absenteeism, loss of concentration, drowsiness and tiredness, as well as development or exacerbation of respiratory symptoms and asthma, headache, and decreased academic performance (GRINESKI et al., 2016, MEIBOUDI et al., 2016; KANCHONGKITTIPHON et al. 2015).

Children are more susceptible to the effects of air contaminants than adults, due to their immature immune and respiratory system, inferior body mass index and breathing pattern (YASSIN and PILLAI 2018, WHO 2006). As a result of the time spent in schools, indoor environmental conditions are among the major contributors of total exposure for children to various air pollutants (LAI et al. 2015, SALTHAMMER et al. 2016; YASSIN and PILLAI 2018, BENNETT et al. 2019).

Biological pollution because of indoor dampness, moisture, or water damage is a challenging environmental health issue. Association between these moisture problems 
and related microbial growth and human health has been extensively documented. In this context, the objective of this study was to characterize the microbial contamination present in the indoor atmosphere of a public school in our city in relation to its impact with the respiratory disorders of those who come to that establishment.

\section{I METHODOLOGY}

\section{Study design}

The present study was carried out in the National College "Rafael Hernández", a public school building located in the urban area of La Plata city, capital of Buenos Aires province, Argentine. Nine classrooms were selected with different characteristics, associated with their location in the building, orientation and ventilation. Three samplings were carried out (during the winter, spring and summer seasons) since the fourth sampling (corresponding to autumn) had to be rejected due to the current situation of the coronavirus pandemic. Therefore, 54 air samples (27 bacterial and 27 fungal samples) were analyzed. The classrooms were selected according to their location in the building and orientation.

\section{Microbiological air sample}

Air samples were collected by a) impaction using an air sampler ("Aquaria" Microflow Alfa, Made in Italy) with a flow rate of $1.5 \mathrm{~L}$ of air per minute for 3 minutes collected in Petri dishes (55 mm diameter) and b) spontaneous sedimentation for 15 minutes in a $90 \mathrm{~mm}$ diameter Petri dishes.

\section{Microorganism recovery}

\section{Fungal isolation}

Isolation and count of filamentous and yeast fungi were performed using Sabouraud and Diclorán 18\% Glicerol Cloranfenicol (DG18) plates. The plates were incubated at $28 \pm$ $2^{\circ} \mathrm{C}$ for a 7 and 2 days incubation period for filamentous and yeast fungi, respectively. The count was reported as colony forming units (CFU). Each of the filamentous fungi colonies that presented different macromorphological characteristics were placed in tubes with inclined Malt Extract Agar (MEA) for isolation and subsequent identification. They were incubated in the same conditions for 7 days. According to their macromorphology (diameter, texture, reverse and obverse of the colonies, color of conidia, production of pigments, sclerotia, and/or structures of sexual reproduction), each isolation was replicated to specific culture media for each case and identified accordingly according to the taxonomic keys of PITT and HOCKING (1997). The yeast colonies were transferred to lysine agar and WL-agar by serial dilution and direct plating to differentiate the yeast of the saccharomyces type from the non-saccharomyces according to the presence/absence of colonies and microscopic 
morphology, respectively (FOWELL, 1965; PALLMANN et al., 2001).

\section{Bacterial isolation}

Agar $\mathrm{R}_{2} \mathrm{~A}$ agar was used as the culture medium for sampling. The incubation for its corresponding enumeration was performed during $48 \mathrm{~h}$ at $37^{\circ} \mathrm{C}$. Then a macroscopic differentiation was carried out by color, texture and appearance. Each colony was transferred to Tryptein Soy Agar (TSA) plates and once developed; they were stained with Gram, to separate each isolate according to its morphology and structure. Simultaneously, the catalase reaction and glucose O/F were performed. The bacteria identification was performed using Matrix Assisted Laser Desorption Ionization- Time of Flight analyzer (MaldiTof MS) with the VITEK ${ }^{\circledR}$ MS commercial system (bioMérieux, Durham, NC) with SARAMIS database.

\section{Determination of physiological parameters}

The following parameters were performed using a DATOSPIR 120A portable spirometer, appropriately calibrated, in a whole in accordance with international recommendations (American Thoracic Society, 1995; American Thoracic Society-European Respiratory Society, 1993).

- FVC (liters): Forced Vital Capacity is the amount of air that the patient can expel in a maximum expiration, after filling his lungs to maximum capacity. A normal or reduced value indicates obstructive diseases, while a reduction of the FVC means restrictive diseases.

- FEV1 (liters): Forced Expiratory Volume that manages to forcely expire the patient in the first second of the maneuver. A low value means obstructive disease.

- FEV1/FVC (\%): It is used in the diagnosis of restrictive and obstructive pulmonary diseases. It represents the percentage of a person's vital capacity that can expire in the first second of exhalation.

- FEF25\%-75\%: Average Forced Expiratory Flow from the moment 25\% of the FVC is exhaled to $75 \%$ of the exhaled FVC.

- PEF (liters/second): Maximum Expiratory Flow obtained from the peak in the expiratory branch of the flow-volume curve.

For this purpose, healthy young people were randomly selected from the different courses attending the school under study, aged between 13 and 17 years, who had voluntarily signed the corresponding informed consent and whose parents expressed the desire to accompany them with it (GARCÍA-RIO et al., 2013). 


\section{I RESULTS AND DISCUSSION}

\section{Microbiological pollutants}

As the prevalence of different fungal genera was the same regardless of the sampling method, the counts were made of Petri dishes of $55 \mathrm{~mm}$ diameter where it allowed us to quantify the contamination per unit time and the occurrence of each fungal genera was estimated based on the frequency of appearance on the Petri dishes of $90 \mathrm{~mm}$ diameter exposed to the environment.

As there was no significant difference between the different sampled sites, the indoor pollutants concentration was reported as the average of all the plates analyzed in each sampling. Table 1 summarizes the mean ( \pm standard deviation) concentration of indoor microbiological pollutants at the different sampling seasons.

\begin{tabular}{ccccccc}
\hline \multirow{2}{*}{$\begin{array}{c}\text { Microbiological } \\
\text { pollutants }\end{array}$} & \multicolumn{2}{c}{ Winter } & \multicolumn{2}{c}{ Spring } & \multicolumn{2}{c}{ Summer } \\
\cline { 2 - 7 } & $\begin{array}{c}\text { Mean (UFC/ } \\
\text { m3. minute) }\end{array}$ & $\begin{array}{c}\text { Standard } \\
\text { deviation (SD) }\end{array}$ & $\begin{array}{c}\text { Mean (UFC/ } \\
\text { m3. minute) }\end{array}$ & $\begin{array}{c}\text { Standard } \\
\text { deviation (SD) }\end{array}$ & $\begin{array}{c}\text { Mean (UFC/ } \\
\text { m3. minute) }\end{array}$ & $\begin{array}{c}\text { Standard } \\
\text { deviation (SD) }\end{array}$ \\
\hline Fungus & $3.5 \times 102$ & $0.3 \times 102$ & $4,2 \times 102$ & $0.7 \times 102$ & $9,1 \times 102$ & $1 \times 102$ \\
\hline Bacteria & 410 & 220 & 314 & 186 & 135 & 45 \\
\hline
\end{tabular}

Table 1. Microbiological pollutants concentration (mean \pm SD) in the different assayed seasons.

\section{Fungal isolation}

The total mean concentration of fungal indoor ranged from $3.5 \times 10^{2}$ and $9.1 \times 10^{2}$ $\mathrm{UFC} / \mathrm{m}^{3}$. minute. The results of this study showed that fungal concentrations were higher during the period of highest vegetation growth in summer, which is in agreement with the findings of other authors (REN et al., 2001; AYDOGDU and ASAN, 2008). The fungi in the indoor air come from the outside air that enters through natural ventilation and also their spores are transported by the students through clothing. Climatic conditions (warm weather and high relative humidity) are the determinants of the higher airborne viable fungal concentrations.

The frequency of occurrence of indoor fungal genera is presented in Figure 1. Eighteen different fungi representing yeast and filamentous groups were identified from indoor air, including spoilage, dermatophytic, dematiaceous fungus, Saccharomyces and non-Saccharomyces yeast. 


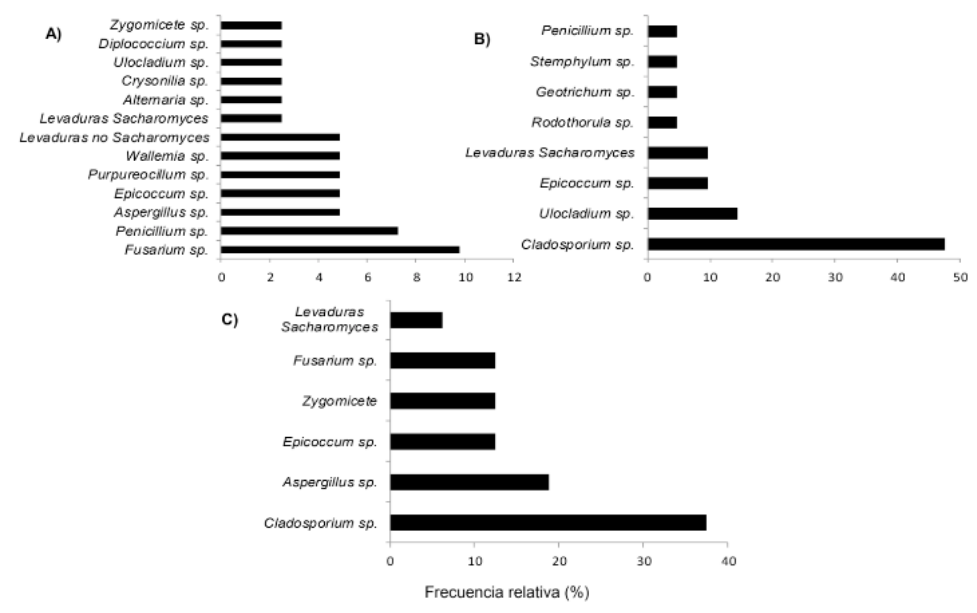

Figure 1. Frequency of occurrence of fungal genera present in indoor air corresponding to $A$ ) Summer, B) Spring and C) Winter

As can be observed, the predominant genera of airborne fungi isolated in indoor air of the college were Cladosporium, Epicoccum, Ulocladium, Aspergillus, Fusarium and Penicillium. Many of the fungal agents present are recognized among the main agents that cause infections on human skin (HAVLICKOVA et al., 2008). Other fungi are found as pathogens responsible for serious respiratory disorders (allergic rhinitis to asthma) and producers of mycotoxins that drastically affect human health (RUGA et al., 2015).

Geotrichum is another of the fungal genera found in air samples and although they are natural contaminants of the environment, they induce infrequent but serious invasive infections exclusively in immunocompromised patients with hematological malignancies and severe neutropenia (GIRMENIA et al., 2005).

During the spring the growth of species belonging to the zygomicetes fungi was excessive, which made the isolation and subsequent identification of many fungal colonies difficult.

Exposure to several of these fungal species is associated with increased peak expiratory flow variability in asthmatic children (BUNDY et al., 2009).

Regarding to the isolated yeasts, they were found in a much smaller proportion than the filamentous fungi. Rodothorula genera and different species belonging to the Saccharomyces type group could be identified, as well as some less of the nonSaccharomyces as shown in figure 2 . 


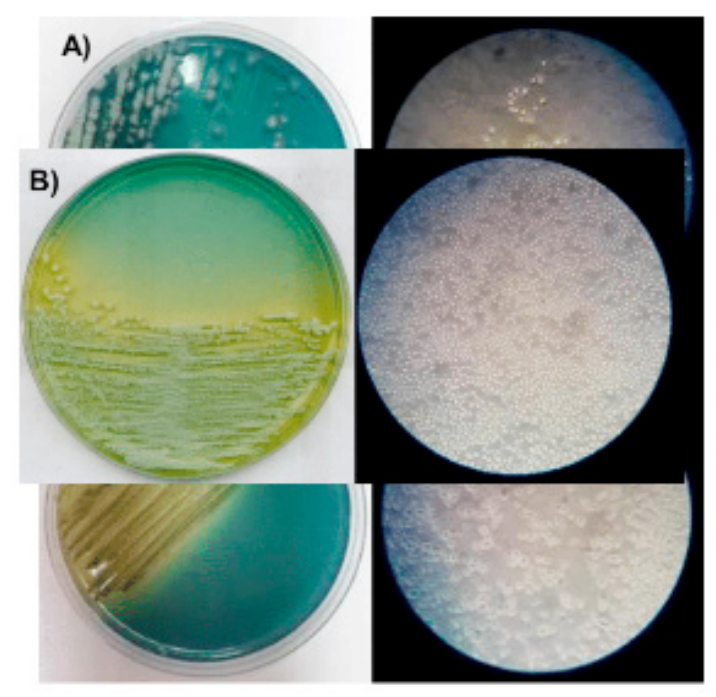

Figure 2. Macro and microscopic characteristics of yeast A) non-Saccharomyces and B) Saccharomyces in WL medium.

\section{Bacteria isolation}

\begin{tabular}{cccc}
\hline Identificated species & Summer & Spring & Winter \\
\hline Bacillus cereus complex & & $\mathrm{X}$ & \\
Pseudomonas orzihabitans & $\mathrm{X}$ & $\mathrm{X}$ & $\mathrm{X}$ \\
Bacillus altitudinis/pumilus & & $\mathrm{X}$ & \\
St. epidermidis & & $\mathrm{X}$ & \\
Micrococcus luteus & & $\mathrm{X}$ & \\
Acinetobacter iwoffi & & $\mathrm{X}$ & \\
Arthrobacter sp. & & $\mathrm{X}$ & \\
Paenibacillus pabuli & $\mathrm{X}$ & & \\
Micrococcus luteus & $\mathrm{X}$ & & $\mathrm{X}$ \\
Paenibacillus durus & $\mathrm{X}$ & & \\
Pseudomonas putida & $\mathrm{X}$ & & $\mathrm{X}$ \\
Bacillus subtilis & $\mathrm{X}$ & & \\
Corynebacterium jeikeium & $\mathrm{X}$ & & \\
Bacillus lichemiformis & $\mathrm{X}$ & \\
Enterobacter ludwigii & $\mathrm{X}$ & $\mathrm{X}$ \\
Kocuria carniphila & $\mathrm{X}$ & $\mathrm{X}$ \\
Staphylococcus conii & & $\mathrm{X}$ \\
Pseudomonas stutzeri & $\mathrm{X}$ & \\
Oenococcus oeni & $\mathrm{X}$ & \\
Exignobacterium acetylicum & & \\
\hline
\end{tabular}




\section{Determination of Pulmonary Function}

Statistical analysis was performed with 171 spirometries that met the selection and acceptability criteria, $45.03 \%$ (77) corresponded to women and $54.97 \%$ (94) to men as show the table 2.

\begin{tabular}{|c|c|c|c|c|c|c|}
\hline \multirow{2}{*}{ Variable } & \multicolumn{3}{|c|}{ Women (N=77) } & \multicolumn{3}{c|}{ Men (N=94) } \\
\cline { 2 - 7 } & Media & SD & p-value & Media & SD & p-value \\
\hline Age (years) & 15.18 & 1.03 & 0.3374 & 14.69 & 0.95 & 0.077 \\
Weight (Kg) & 55.70 & 10.74 & $<0.01$ & 64.06 & 11.84 & $<0.01$ \\
Height (cm) & 160.90 & 0.06 & 0.1348 & 171.30 & 0.07 & 0.4855 \\
FVC (I) & 3.19 & 0.58 & 0.0799 & 4.06 & 0.68 & 0.8079 \\
FEV1 (I) & 2.90 & 0.44 & 0.7779 & 3.64 & 0.61 & 0.0846 \\
FEV1/FVC & 91.38 & 7.85 & $<0.01$ & 89.92 & 6.73 & 0.0181 \\
FEF25\%-75\% (I/s) & 3.44 & 3.98 & 0.4896 & 4.85 & 0.95 & 0.8779 \\
PEF (I/s) & 5.48 & 1.05 & 0.3105 & 6.77 & 1.22 & 0.6909 \\
\hline
\end{tabular}

Table 2. Variables under study according to sex.

\section{I CONCLUSION}

Mold and bacteria monitoring shows differences in the found genera/species in the assayed seasons of the year, which is correlated with the variation in environmental conditions. As for the spirometric parameter values of the study population, they are within normal values, according to the international literature. When compared with the international bibliography (CASAN et al., 1993), they show to be slightly smaller, highlighting the importance of having specific equations to the region under study.

In future studies, an attempt will be made to correlate the found microorganisms with the profiles of volatile metabolites organic compounds (MVOC's) and their effects on the respiratory health of a group of adolescents from La Plata city.

\section{ACKNOWLEDGEMENTS}

The authors acknowledge the financial support of the National Council of Scientific and Technical Research (CONICET) and the National University of La Plata (UNLP) which supported this study through grants. 


\section{REFERENCES}

AMERICAN THORACIC SOCIETY (ATS). Standardization of spirometry. American Journal of Respiratory and Critical Care Medicine, v.152, p.1107-1136, 1995.

AMERICAN THORACIC SOCIETY (ATS) -EUROPEAN RESPIRATORY SOCIETY (ERS) Statement on respiratory mechanics in infants: physiologic evaluation in health and disease. European Respiratory Journal, v .6, p. 279-310, 1993

AYDOGDU H.; ASAN A., Airborne fungi in child day care centers in Edirne City, Turkey, Environmental Monitoring and Assessment, v. 147, p. 423-444, 2008.

BALOCH, R. M.; MAESANO, C. N.; CHRISTOFFERSEN, J.; BANERJEE, S.; GABRIEL, M.; CSOBOD, E.; DE OLIVEIRA FERNANDES, E.; ANNESI-MAESANO, I. Indoor air pollution, physical and comfort parameters related to schoolchildren's health: data from the European SINPHONIE study. Science of the Total Environment, 10.1016/j.scitotenv.2020.139870, 2020.

BENNETT, J.; DAVY, P.; TROMPETTER, B.; WANG, Y.; PIERSE, N.; BOULIC, M.; PHIPPS, R.; HOWDEN-CHAPMAN, P. Sources of indoor air pollution at a New Zealand urban primary school; a case study. Atmospheric Pollution Research, v. 10, p. 435-444, 2019.

BUNDY, K. W.; GENT, J. F.; BECKETT, W.; BRACKEN, M. B.; BELANGER, K.; TRICHE, E.; LEADERER, B. P. Household airborne Penicillium associated with peak expiratory flow variability in asthmatic children. Annals of Allergy, Asthma \& Immunology, v. 103, p. 26-30, 2009.

CASAN, P.; ROCA, J.; SANCHIS, J. Spirometric response to a bronchodilator. Reference values for healthy children and adolescents. Bulletin Européen de Physiopathologie Respiratoire, v. 19, p. 567-569, 1993.

CHITHRA, V.; NAGENDRA, S. A review of scientific evidence on indoor air of school building: pollutants, sources, health effects and management. Asian Journal of Atmospheric Environment, v. 12, p. 87108, 2018.

FOWELL, R. R. The identification of wild yeast colonies on lysine agar. Journal of Applied Bacteriology, v. 28, p. 373-383, 1965.

GARCÍA-RÍO, F.; CALLE, M.; BURGOS, F.; CASAN, P.; DEL CAMPO, F.; GALDIZ, J.; GINER, J.; GONZÁLEZ-MANGADO, N.; ORTEGA, F.; PUENTE MAESTU, L. Normativa SEPAR: Espirometría. Archives of Bronconeumology, v. 49, p 388-401, 2013.

GIRMENIA, C.; PAGANO, L.; MARTINO, B.; D'ANTONIO, D.; FANCI, R.; SPECCHIA, G.; MELILLO, L.; BUELLI, M.; PIZZARELLI, G.; VENDITTI, M.; MARTINO, P. Invasive infections caused by Trichosporon species and Geotrichum capitatum in patients with hematological malignancies: A retrospective multicenter study from Italy and review of the literature. Journal of Clinical Microbiology, v. 43, p. 1818-1828, 2005.

GRINESKI, S. E.; CLARK-REYNA, S. E.; COLLINS, T. W. School-based exposure to hazardous air pollutants and grade point average: A multi-level study. Environmental Research, v. 147, p. 164-171, 2016. 
GUAIS, A.; BRAND, G.; JACQUOT, L.; KARRER, M.; DUKAN, S.; GREVILLOT, G.; MOLINA, T. J.; BONTE, J.; REGNIER, M.; SCHWARTZ, L. Toxicity of carbon dioxide: a review. Chemical Research in Toxicology, v. 24, p. 2061-2070, 2011.

HAVLICKOVA, B.; CZAIKA, V. A.; FRIEDRICH, M. Epidemiological trends in skin mycoses worldwide. Mycoses, v. 51, p. 2-15, 2008.

KANCHONGKITTIPHON, W.; MENDELL, M.; GAFFIN, J.; WANG, G.; PHIPATANAKUL, W. Indoor environmental exposures and exacerbation of asthma: an update to the 2000 review by the Institute of Medicine. Environmental Health Perspectives, v. 123, p. 6-20, 2015.

LAI, P. S.; SHEEHAN, W. J.; GAFFIN, J. M.; PETTY, C. R.; COULL, B. A.; GOLD, D. R.; PHIPATANAKUL, W. School endotoxin exposure and asthma morbidity in inner-city children. Chest, v. 148, p. 1251-1258, 2015.

LAZOVIC, I.; JOVASEVIC-STOJANOVIC, M.; ZIVKOVIC, M.; TASIC, V.; STEVANOVIC, Z. PM and $\mathrm{CO} 2$ variability and relationship ni different school environments. Chemical Industry \& Chemical Engineering Quarterly, v. 21, p. 179-187, 2015.

MADUREIRA, J.; ALVIM-FERRAZ, M.; RODRIGUES, S.; GONÇALVES, C.; AZEVEDO, M.; PINTO, E.; MAYAN, O. Indoor air quality in schools and health symptoms among Portuguese teachers. Human and Ecological Risk Assessment, v. 15, p. 159-169, 2009.

MADUREIRA, J.; PACIÊNCIA, I.; OLIVEIRA FERNANDES, E. Levels and indoor-outdoor relationships of size-specific particulate matter in naturally ventilated Portuguese schools. Journal of Toxicology and Environmental Health: Part A, v. 75, p. 1423-1436, 2012.

MADUREIRA, J.; PACIÊNCIA, I.; RUFO, J.; RAMOS, E.; BARROS, H.; TEIXEIRA, J.; OLIVEIRA FERNANDES, E. Indoor air quality in schools and its relationship with children's respiratory symptoms. Atmospheric Environment, v. 118, p. 145-156, 2015.

MEIBOUDI, H.; LAHIJANIAN, A.; SHOBEIRI, S. M.; JOZI, S. A.; AZIZINEZHAD, R. Creating an integrative assessment system for green schools in Iran. Journal of Cleaner Production, v. 119, p. 236-246, 2016.

MILLER MR, CRAPO R, HANKINSON J, BRUSASCO V, BURGOS F, CASABURI R, et al. General considerations for lung function testing. European Respiratory Journal,v. 26, p.153-161, 2005.

PALLMANN, C. L.; BROWN, J. A.; OLINEKA, T. L.; COCOLIN, L.; MILLS, D. A.; BISSON, L. F. Use of WL medium to profile native flora fermentations. American Journal of Enology and Viticulture, v. 52: 3, 2001.

PITT, J. I.; HOCKING, A. D. Fungi and food spoilage. CSIRO Division of Food Science and Technology Sydney Accademic, Press. Australia, 1997.

QUANJER, P. H. H.; STANOJEVIC, S.; COLE, T. J.; BAUR, X.; HALL, G. L.; CULVER, B.; ENRIGHT, P. $\mathrm{L}$. Multi-ethnic reference values for spirometry for the 3-95 year age range: the global lung function 51 2012 equations. European Respiratory Journal, v. 40, p. 1324-1343, 2012. 
REN, P.; JANKUN, T.; BELANGER, K.; BRACKEN, M.; LEADERER B. The relation between fungal propagules in indoor air and home characteristics, Allergy, v. 56, p. 419-424, 2001.

SALONEN, H.; DUCHAINE, C.; MAZAHERI, M.; CLIFFORD, S.; LAPPALAINEN, S.; REIJULA, K.; MORAWSKA, L. Airborne viable fungi in school environments in different climatic regions - a review. Atmospheric Environment, v. 104, p. 186-194, 2015.

SALTHAMMER, T.; UHDE, E.; SCHRIPP, T.; SCHIEWECK, A.; MORAWSKA, L.; MAZAHERI, M.; CLIFFORD, S.; HE, C.; BUONANNO, G.; QUEROL, X. Children's well-being at schools: Impact of climatic conditions and air pollution. Environmental International, v. 94, p. 196-210, 2016.

WHO, 2006. Principles for Evaluating Health Risks in Children Associated with Exposure to Chemicals. World Health Organization.

YASSIN, M.; PILLAI, A. Monitoring of volatile organic compounds in different schools: a determinant of the indoor air quality. International Journal of Environmental Sciences and Technology, v. 16, p. 2733-2744, 2018. 


\section{SOBRE OS ORGANIZADORES}

LUIS HENRIQUE ALMEIDA CASTRO - Possui graduação em nutrição pela Universidade Federal da Grande Dourados concluída em 2017 com a monografia "Analysis in vitro and acute toxicity of oil of Pachira aquatica Aublet”. Ainda em sua graduação, no ano de 2013, entrou para o Grupo de Pesquisa Biologia Aplicada à Saúde sendo um de seus membros mais antigos em atividade realizando projetos de ensino, pesquisa e extensão universitária desde então. Em 2018 entrou no Curso de Mestrado no Programa de Pós-Graduação em Ciências da Saúde da Universidade Federal da Grande Dourados com o projeto de pesquisa: "Avaliação da Toxicidade Reprodutiva Pré-clínica do Óleo da Polpa de Pequi (Caryocar brasiliense Camb.)" no qual, após um ano e seis meses de Academia, obteve progressão direta de nível para o Curso de Doutorado considerando seu rendimento acadêmico e mérito científico de suas publicações nacionais e internacionais; além disso, exerce no mesmo Programa o cargo eletivo (2018-2019) de Representante Discente. Em 2019 ingressou também no Curso de Especialização em Nutrição Clínica e Esportiva pela Faculdade Venda Nova do Imigrante. Atua desde 2018 enquanto bolsista de Pós-Graduação pela Coordenação de Aperfeiçoamento de Pessoal de Nível Superior (CAPES) desenvolvendo pesquisas em duas principais linhas de atuação: nutrição experimental, na qual desenvolve estudos farmacológicos e ensaios de toxicidade com espécies vegetais de interesse para a população humana; e, nutrição esportiva, no tocante à suplementação alimentar, metabolismo energético, fisiologia do exercício e bioquímica nutricional. Atualmente é revisor científico dos periódicos Journal of Nutrition and Health Sciences, Journal of Human Nutrition and Food Science e do Journal of Medicinal Food. É ainda membro do Corpo Editorial do Journal of Human Physiology e membro do Conselho Técnico Científico da própria Editora Atena.

FERNANDA VIANA DE CARVALHO MORETO - Possui graduação em Nutrição pelo Centro Universitário da Grande Dourados (2008), pós-graduação em Terapia Nutricional, Nutrição Clínica e Fitoterapia pela Faculdade Ingá - Maringá (2012). Especialização em Nutrição Esportiva pela Faculdade de Ensino Superior de São Miguel do Iguaçu - FAESI (2015). Nutricionista Clínica e Esportista, com mais de 10 anos de experiência em consultório nutricional, com foco no atendimento personalizado em crianças, adultos, gestantes, idosos, praticantes de atividades físicas e atletas, visando o cuidado, a saúde e o bem-estar. Com o perfil clínico em legitimar a Nutrição Baseada em Evidência em ser acessível para todos, sempre utilizou do que existe de maior evidência em nutrição para prevenir e tratar doenças. Na sua trajetória profissional, foi nutricionista do Programa Mesa Brasil SESC (2010-2016), responsável por ministrar Oficinas Culinárias de Aproveitamento Integral dos Alimentos e Cursos de Higiene e Manipulação dos Alimentos de acordo com as normas da Vigilância Sanitária. Atuou como docente, cargo professora substituta, na Universidade Federal da Grande Dourados (UFGD) em diversas disciplinas, como Nutrição e Esportes, Higiene e Controle de Qualidade de Alimentos, Composição de Alimentos, Técnica Dietética e Ética Profissional e Bioética (2017 - 2019). Atualmente é acadêmica bolsista da CAPES no curso de Mestrado do Programa de Alimentos, Nutrição e Saúde da Universidade Federal da Grande Dourados (2019). Membro do Grupo de Pesquisa Biologia Aplicada à Saúde. Pesquisadora, atuante em ensaios pré-clínicos visando avaliar a ação farmacológica de compostos ativos naturais sobre os sistemas orgânicos (toxicidade e genotoxicidade) e fatores de risco associados à saúde. Atua principalmente nos 
seguintes temas: fitoterapia, nutrição clínica e esportiva.

THIAGO TEIXEIRA PEREIRA - Possui graduação em Educação Física Licenciatura e Bacharelado pela Universidade Católica Dom Bosco - UCDB (2018). Concluiu especialização em Educação Especial pela Universidade Católica Dom Bosco em 2019. Ingressou na pós-graduação (Stricto Sensu) a nível de mestrado em 2019 pela Fundação Universidade Federal da Grande Dourados - UFGD, área de concentração em Farmacologia, no qual realiza experimentos em animais na área de toxicologia e endocrinologia, associando intervenção com extratos de plantas e/ou ervas naturais e exercício físico. É membro do Grupo de Pesquisa de Biologia Aplicada à Saúde, cadastrado no CNPq e liderado pela Profa. Dra. Silvia Aparecida Oesterreich. Em 2019, foi professor tutor do curso de Graduação Bacharel em Educação Física, modalidade Educação à Distância, pela Universidade Norte do Paraná polo de Campo Grande-MS (UNOPAR/CG). Foi revisor dos periódicos Lecturas: Educacíon Física y Desportes e Arquivos de Ciências da Saúde da UNIPAR. Possui experiência profissional em treinamento funcional e musculação, avaliação antropométrica, testes de aptidão física e cardiovasculares, montagem de rotinas de treinamento, orientação postural e execução de exercícios, periodização do treinamento e treinamento resistido com enfoque em hipertrofia máxima e promoção da saúde. Atualmente está desenvolvendo estudos de metanálise com o fruto Punica granatum L., bem como a ação de seus extratos em animais da linhagem Wistar, associado ao exercício físico de força. Recentemente, participou como coautor de um estudo de metanálise inédita intitulada: Comparative Meta-Analysis of the Effect of Concentrated, Hydrolyzed, and Isolated Whey Protein Supplementation on Body Composition of Physical Activity Practitioners, que buscou verificar a eficiência de whey protein dos tipos concentrado, isolado e hidrolisado comparado a placebos isocalóricos sobre os desfechos de composição corporal em adultos saudáveis praticantes de atividade física. 
ÍNDICE REMISSIVO

A

Aceitabilidade 66, 70, 72, 73

Análise microbiológica 1, 19

Análise Postural 6

Atividade Física 6, 8, 9, 12, 14, 124

Avaliação higiênico-sanitária 46

B

Biocompatibilidade 76, 77, 78

BIOCOMPATIBILIDADE 76

Boas práticas de fabricação 22, 38, 42, 91, 93, 96

C

Caprinos 76, 78, 83

Células-Tronco 76, 77, 78, 79, 80, 81, 82

Células-Tronco Mesenquimais 76, 77, 78, 80, 81, 82

Coliformes 10, 1, 3, 4, 18, 19, 20, 21, 22, 44, 46, 48, 54, 69, 71

Contaminação 4, 19, 21, 22, 23, 36, 37, 38, 41, 48, 53, 92, 96, 97

Contaminação física 36, 37, 38

Coping Religioso 100, 102, 103, 104, 105, 108

E

Escolares 6, 8, 9, 10, 12, 13, 14, 15, 16

Espiritualidade 100, 101, 102, 103, 106, 107, 108, 109, 110, 111

Estado Nutricional $6,7,9,13,15,16,47$

F

Feira 22, 56

Fígado 58, 59, 61, 62, 63, 64

Frigorífico 91, 95, 96, 98

H

Hepatite 58, 59, 60, 61, 62, 63, 64, 65

Hepatite Autoimune 58, 59, 61, 62, 63, 64, 65

Histopatologia 58, 62, 63 
Idosos 26, 27, 28, 29, 30, 31, 32, 33, 34, 35, 123

M

Mandioca $1,2,3,4,5,17,18,19,20,21,22,23,24,25,36,37,38,39,40,42,43$

Matadouro 98

Matriz porosa $76,77,78,81$

Microbiologia 18, 24, 73, 74, 86, 99

Micronúcleo 84, 85, 88, 90

Mucosa Oral 84, 85, 86, 88, 89, 90

Mutagenicidade 84

0

Óleo de buriti 76, 78, 81, 82

$\mathbf{P}$

Pescado 44, 45, 46, 47, 48, 49, 50, 51, 52, 53, 54, 55, 56, 57, 67, 68, 74, 98

Postura $6,7,8,9,10,12,14,15,16$

Q

Qualidade de vida 7, 35, 100,101, 102, 103, 106, 107, 108, 109

Qualidade microbiológica 1, 3, 17, 18, 19, 24, 46, 49, 56

$\mathbf{R}$

Risco de queda 29

T

Tapioca 17, 18, 19, 20, 21, 25, 36, 37, 38, 39, 40

Tilápia do Nilo 66, 71, 75 


\title{
Política, Planejamento e Gestão em
}

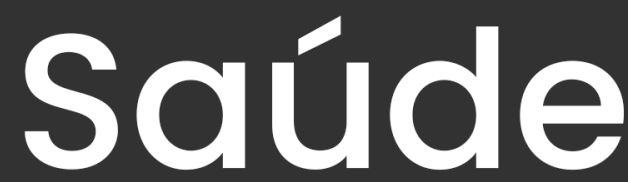

\author{
www.atenaeditora.com.br \\ contato@atenaeditora.com.br \\ 우 @atenaeditora \\ f www.facebook.com/atenaeditora.com.br
}




\title{
Política, Planejamento e Gestão em
}

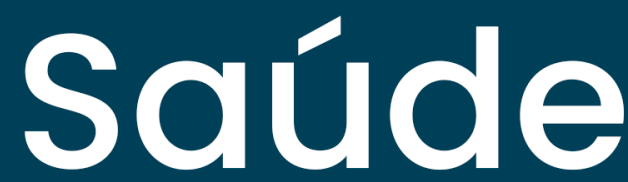

\author{
www.atenaeditora.com.br \\ contato@atenaeditora.com.br \\ 우 @atenaeditora \\ f www.facebook.com/atenaeditora.com.br
}

